\title{
Retreat of Wurtenkees, European East Alps, since 1850
}

\author{
W. Schöner, ${ }^{1}$ I. Auer,${ }^{2}$ R. Böhm, ${ }^{2}$ N. Hammer,${ }^{2}$ T. Wiesinger ${ }^{1}$ \\ ${ }^{1}$ Institut für Meteorologie und Geophysik, Universität Wien, 1190 Vienna, Austria \\ ${ }^{2}$ Zentralanstalt für Meteorologie und Geodynamik, Klimaabteilung, 1190 Vienna, Austria
}

\begin{abstract}
The retreat of Wurtenkees, a glacier of about $1 \mathrm{~km}^{2}$ in the European East Alps, is described by measurement of frontal change, interpretation of maps and a computed mass-balance series. Since 1850, Wurtenkees has been one of the most strongly retreating glaciers in this region. Mass balance has been measured since 1982. Measured values of the accumulation area ratio and the equilibrium-line altitude as well as a degreedays model are used for the description of the activity conditions of the glacier. Under present climatic conditions Wurtenkees would need a lowering of the mean air temperature during the summer season of $1-1.5^{\circ} \mathrm{C}$ to return to a balanced mass budget. With predicted global warming, the glacier is likely to disappear early in the 21st century.
\end{abstract}

\section{INTRODUCTION}

Wurtenkees is a small glacier south of the main ridge of the Hohe Tauern in the European East Alps. As this glacier is situated in a mountain region with only small areas above $3000 \mathrm{~m}$ and with a mean equilibrium-line altitude (ELA) in the same range of elevation it is very sensitive to climate change and variability (Auer and others, 1995). With an area of about $1 \mathrm{~km}^{2}$ in 1991, Wurtenkees is one of the largest glaciers of the Goldberggruppe (Fig. 1). In 1982 it was chosen for intensive glaciological studies, first because its retreat behaviour since 1850 contrasts with that of adjacent glaciers (Böhm, 1984), and secondly because its vicinity to the Sonnblick observatory (with long-term climatic time series on a mountain top $3100 \mathrm{~m}$ a.s.l.) enables investigation of the relation between the glacier and the climate. Auer and others (1995) present a detailed report of the glaciological investigations at Wurtenkees.

The strong areal retreat of all glaciers of the Goldberggruppe to about $10-50 \%$ of the area in 1850 is described by Böhm (1994), who also concluded that the glaciers of the Goldberggruppe are most probably not in equilibrium with the present climatic conditions despite the strong areal retreat. For Wurtenkees this strong retreat has been documented by means of a reconstructed mass-balance record dating as far back as the end of the 19th century (Hammer, 1994). This paper describes the retreat of Wurtenkees since 1850, by means of frontal change measurements, interpretation of maps and mass-balance data.

\section{RETREAT OF WURTENKEES SINGE 1850}

For a description of the retreat of Wurtenkees since 1850, annual measurements of frontal change, topographic maps, and a reconstructed mass-balance series (Hammer, 1994) are available. These historic data show a weak retreat of Wurtenkees during the period 1850-1920 (Fig. 2). Positive mass balances of Wurtenkees in the period around 1915 resulted in a weak advance around 1920 . Since this reduced advance, Wurtenkees has been one of the strongest retreat- ing glaciers of the European East Alps, continuing its retreat uninterruptedly during the periods of positive mass balance of the 1960s and the late 1970s/early 1980s when many glaciers in the region advanced. During the advance period around 1980, $75 \%$ of the glaciers of the East Alps were advancing (Patzelt and Aellen, 1990).

During the 1970s Wurtenkees divided into two parts. This division has resulted in a strong retreat of the glacier front of the eastern part of Wurtenkees (Fig. 2). Whereas the eastern part of Wurtenkees is still active, the western part will vanish completely in the near future if present climatic conditions persist. This statement can be derived, for example, from observation of the size of the accumulation zone. Using annual photographs taken at the end of the ablation season, observation of the size of the accumulation area was performed for the western part of Wurtenkees, which has been non-existent in most of the last 10 years.

\section{THE EVOLUTION OF WURTENKEES, 1983-95}

The mass balance of eastern Wurtenkees has been measured by the direct method according to international standards (Østrem and Brugman, 1991) since balance year 1982/83. These mass-balance investigations include the measurement of winter balance and annual net balance. The measurements show a negative annual balance for all years of the investigation period except for the balance year 1983/84 (Fig. 3). Eastern Wurtenkees had an average mass loss of $834 \mathrm{~kg} \mathrm{~m}^{-2} \mathrm{a}^{-1}$ in the period 1983-95. This value is somewhat more negative than the mean of other glaciers of the East Alps (Auer and others, 1995).

The mass balance of eastern Wurtenkees is correlated with the accumulation area ratio (AAR) and the ELA. Unfortunately, for five of the investigated years the ELA of eastern Wurtenkees was higher than the highest parts of the glacier. From Figure 4 we can derive an AAR of about 0.45 for the equilibrium state of eastern Wurtenkees. Under present climatic conditions, the ratio is, however, 0.17 (mean of the period 1983-95).

Computed values of the vertical movement of the glacier 


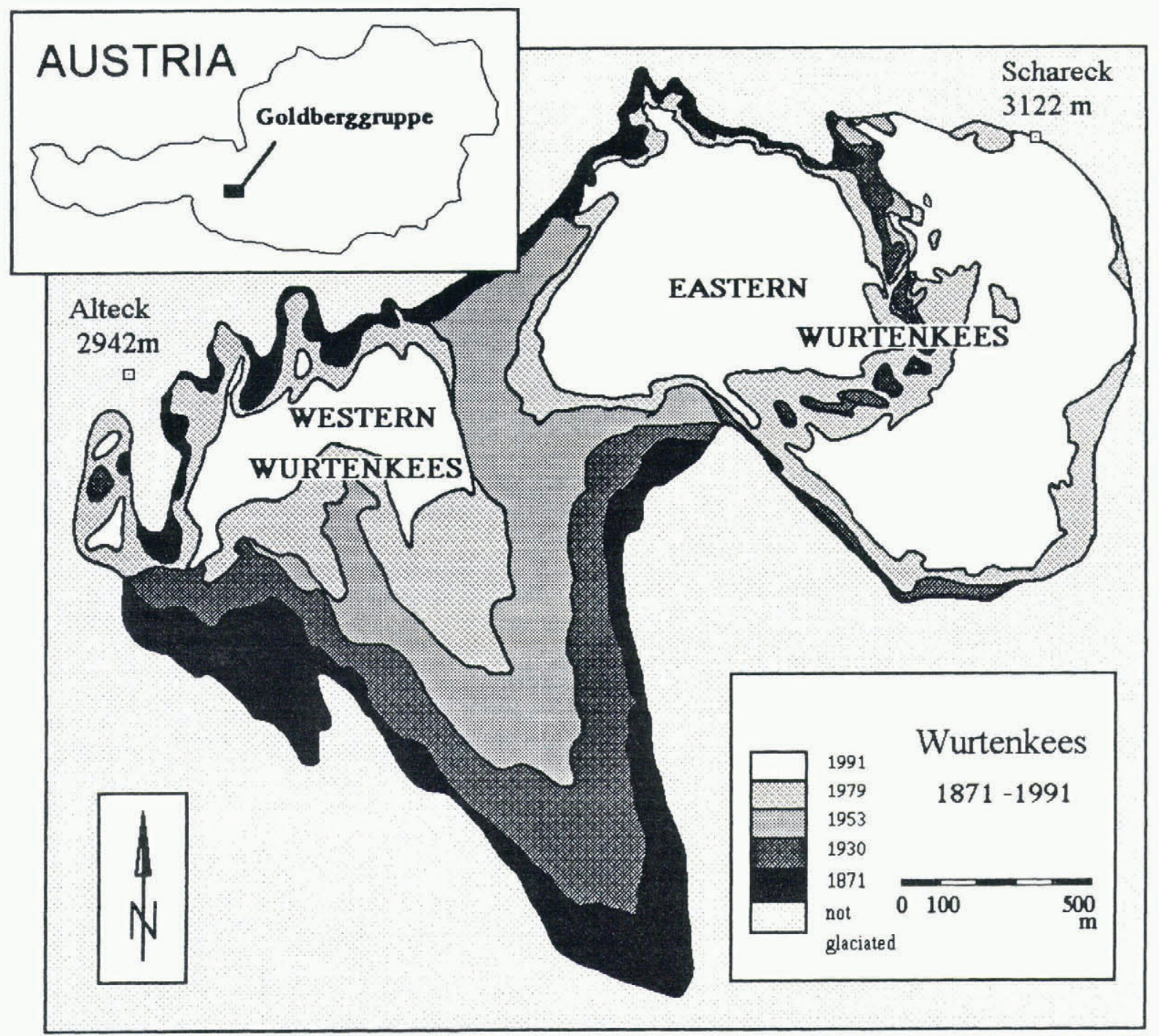

Fig. 1. Topographic map of Wurtenkees in 1991.

surface of eastern Wurtenkees by means of ablation stake measurements in 1983 show values typical of a strongly retreating glacier (Auer and others, 1995). At each elevation the ablation greatly exceeded the vertical movement. Measurements of the horizontal movement of the glacier surface show a reduction from about $6 \mathrm{ma}^{-1}$ to less than

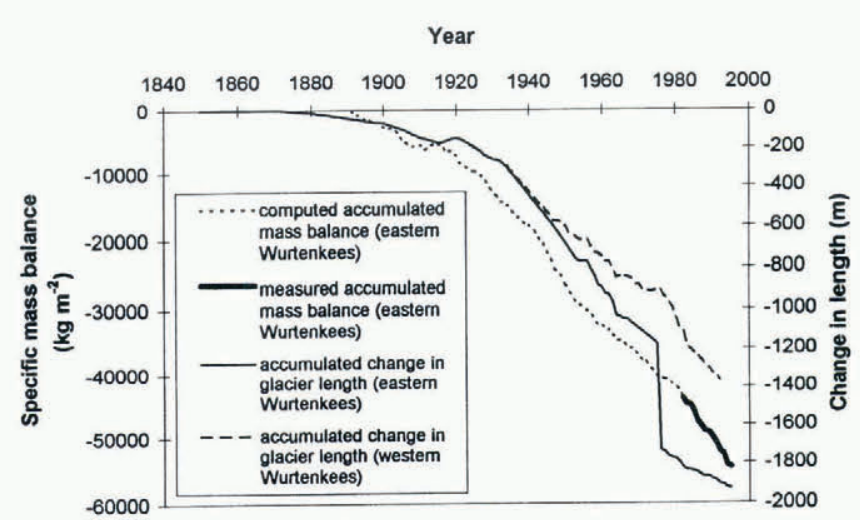

Fig. 2. Accumulated change in glacier length since 1850, computed accumulated mass balance since 1891 (data from Hammer, 1994) and measured accumulated mass balance since 1983 of Wurtenkees.
$3 \mathrm{~m} \mathrm{a}^{-1}$ in the period 1983-95. These values are typical for a strongly retreating glacier at the limit of its existence.

As with other glaciers of the European Alps, the annual mass balance of Wurtenkees is primarily determined by the summer balance, whereas the winter accumulation is less significant. This is shown by the relative correlations of the

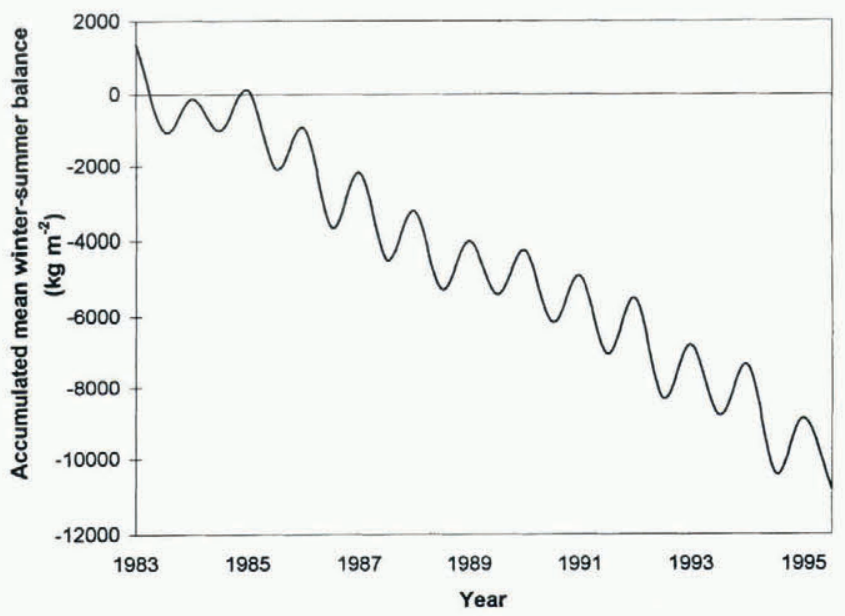

Fig. 3. Accumulated mean winter-summer mass-balance curve of eastern Wurtenkees for the period 1982/83-1994/95. 


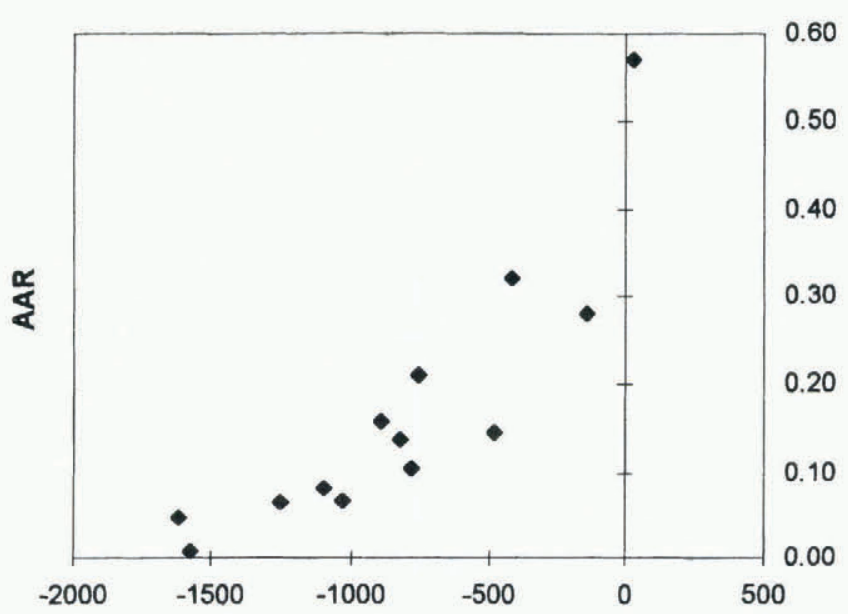

Spec. annual mass balance $\left(\mathrm{kg} \mathrm{m}^{-2}\right)$

Fig. 4. Specific annual mass balance vs accumulation area ratio (AAR) of eastern Wurtenkees for the period 1982/83$1994 / 95$.

specific annual balance $(b)$ to the specific winter balance $\left(b_{\mathrm{w}}\right)$ and to the specific summer balance $\left(b_{\mathrm{s}}\right)$ (Fig. 5). Whereas $b_{\mathrm{s}}$ is well correlated to $b(r=0.95)$, the correlation between $b_{\mathrm{w}}$ and $b$ is weak $(r=0.05)$. With the high correlation between $b_{\mathrm{s}}$ and $b$ it is feasible to apply the positivedegree-days method for the reconstruction of the mass balance of Wurtenkees using meteorological data from the nearby Sonnblick observatory (Hammer, 1994).

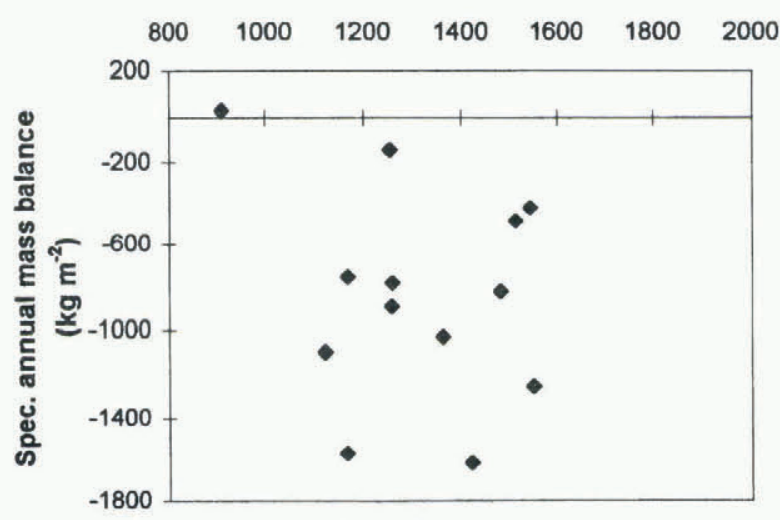

Spec. winter mass balance $\left(\mathrm{kg} \mathrm{m}^{-2}\right)$

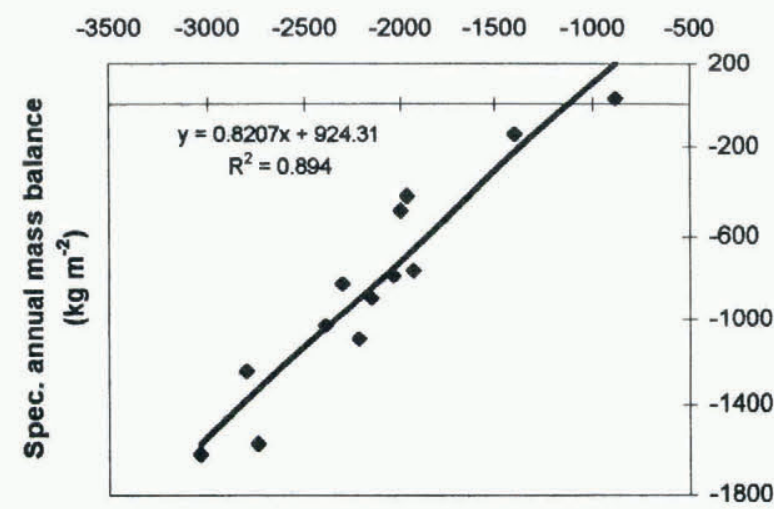

Spec. summer mass balance $\left(\mathrm{kg} \mathrm{m}^{-2}\right)$

Fig. 5. Specific winter mass balance and specific summer mass balance vs specific annual balance of eastern Wurtenkees for the period 1982/83-1994/95.
Since 1850, Wurtenkees has retreated about $1400 \mathrm{~m}$ in the western part and about $1900 \mathrm{~m}$ in the eastern part. It now covers $37 \%$ of its area in 1850 , representing a loss of about $50 \mathrm{~m}$ of ice thickness ( $200 \mathrm{~m}$ at the former terminus) and about $200 \times 10^{9} \mathrm{~kg}$ of mass (Auer and others, 1995).

The eastern part of Wurtenkees itself separated into two parts in 1990 (Fig. 1). Since these two parts are connected via various accumulation processes (wind drift, avalanches, etc.) the investigation of the two parts as one entire glacier is useful. The exchange processes by wind between the two parts of the glacier during the accumulation period are a result of the convex-shaped glacier surface not shaded by the surrounding ridges of the higher part of the glacier.

\section{WILL WURTENKEES VANISH COMPLETELY IN THE NEAR FUTURE?}

Under present climatic conditions the surface of eastern Wurtenkees is lowered by about $1 \mathrm{~m}$ of ice thickness per year. Since Wurtenkees is used as a glacier ski resort and its meltwater is also stored for a power plant, the question arises whether the glacier will vanish completely in the near future. One problem of such investigations is the unknown ice thickness and ice volume of Wurtenkees, as a scismic depth measurement performed in 1977 had errors too large for the determination of the bottom topography of the glacier (Auer and others, 1995).

Figure 4 indicates a mean AAR of about 0.2 under present climatic conditions and an equilibrium AAR of about 0.45 . The accumulation area has an average area of $0.2 \mathrm{~km}^{2}$ (period 1983-95). The equilibrium state under present climatic conditions will thus be reached for a total glacier area of about $0.5 \mathrm{~km}^{2}$. The retreat rate of eastern Wurtenkees between 1979 and 1992 varied little. Extrapolating this linear trend, eastern Wurtenkees will be reduced to an area of $0.5 \mathrm{~km}^{2}$ around 2010 . Under the assumptions mentioned above, the glacier will reach an equilibrium state at this point. However, a linear extrapolation does not accurately predict the expected outcome since the retreat rate is likely to slow as equilibrium is approached.

The prediction of the evolution of eastern Wurtenkees shown above is based on the assumption of present climatic conditions. If we now assume a global warming of the atmosphere in the near future, the glacier's retreat will not be reduced at the beginning of the 2lst century. Under the assumption of a warming of $1-2^{\circ} \mathrm{C}$ up to the year 2030, the ELA would be elevated by $170-340 \mathrm{~m}$ (Kuhn, 1989; Kuhn and others, 1993), if a simple prediction equation is applied. This would raise the ELA above the highest parts of the glacier, which would vanish more or less completely in the early decades of the 2lst century.

An increase of the air temperature by $1{ }^{\circ} \mathrm{C}$ for the entire ablation period (beginning of May to end of September = $153 \mathrm{~d}$ ) is equivalent to an increase of the degree-days sum of 153 units. 153 degree days is equivalent to a change of the specific mass balance of about $600 \mathrm{~kg} \mathrm{~m}^{-2}$ according to the regression equation of Hammer (1994). A more negative specific mean mass balance of about $600-1200 \mathrm{~kg} \mathrm{~m}^{-2}$ (resulting from a temperature increase of $1-2^{\circ} \mathrm{C}$ ) reduces the accumulation area to more or less zero (Fig. 4). This approximation confirms the proposition that Wurtenkees will vanish completely with a warming of $1-2^{\circ} \mathrm{C}$. It is also evident from Figure 4 that eastern Wurtenkees needs a lower- 
ing of about $1-1.5^{\circ} \mathrm{C}$ of the mean air temperature during the ablation season to return to a balanced mass budget under present climatic conditions.

\section{REFERENGES}

Auer, I., R. Böhm, N. Hammer, W. Schöner, T. Wiesinger and W. Winiwarter, 1995. Glaziologische Untersuchungen im Sonnblickgebiet: Forschungsprogramm Wurtenkees. Österreich. Beitr. Meteorol. Geophys. 12.

Böhm, R. 1984. Monographie der Gletscher der Goldberggruppe in den Hohen Tauern. Teil 1: Das Wurtenkees, 79-81. Jahrb. Sonnblickver. 19811983, 3-59.

Böhm, R. 1994. Kartometrische Daten der Vergletscherung der Goldberggruppe in den Hohen Tauern 1850-1992. Z. Gletscherkd, Glazialgeol., 29 (2), 1993, 133-152.
Hammer, N. 1994. Wurtenkees: Rekonstruktion einer 100jährigen Reihe der Gletschermassenbilanz. Z. Gletscherkd. Glazialgeol., 29 (1), 1993, 15-37.

Kuhn, M. 1989. The response of the equilibrium line altitude to climatic fluctuations: theory and observations. In Oerlemans, J., ed. Glacier fluctuations and climatic change. Dordrecht, etc., Kluwer Academic Publishers, 407-417.

Kuhn, M., F. Obleitner, H.P. Nachtnebel and G. Reichel. 1993. Hydrologie. Auswirkungen von Klimaänderungen auf den Wasserhaushalt Österreichs. In Österreichische Akademie der Wissenschaften, ed. Bestandsaufnahme anthropogene Klimaänderungen: mögliche Auswirkungen auf Österreich - mögliche Massnahmen in Österreich. Wien, Verlag der ÖAW, $4.1-4.67$.

Østrem, G. and M. Brugman. 1991. Glacier mass-balance measurements. $A$ manual for field and office work. Saskatoon, Sask., Environment Canada National Hydrology Research Institute. (NHRI Science Report 4.)

Patzelt, G. and M. Aellen. 1990. Gletscher. Eidg. Tech. Hochschule, Zürich. Versuchsanst. Wasserbau, Hydrol. Glaziol. Mitt. 108, 4969. 